\title{
Pengaruh Auditory, Intellectually, Repetition (AIR) dengan Pendekatan Lesson Study terhadap Kemampuan Pemecahan Masalah Matematis
}

\author{
Elma Agustiana1, Fredi Ganda Putra1', Farida1 \\ 1Universitas Islam Negeri Raden Intan Lampung. Jalan Endro Suratmin, Sukarame, \\ Bandar Lampung 35133, Indonesia. \\ *Corresponding Author. E-mail : elmaagustiana485@gmail.com
}

Received : 09-11-2017; Revised: 06-01-2018; Accepted : 29-01-2018

\begin{abstract}
Abstrak
Tujuan dari penelitian ini adalah untuk mengetahui apakah ada perbedaan rata-rata penerapan model pembelajaran Auditory, intellectually, Repetition (AIR) dengan pendekatan lesson study terhadap kemampuan pemecahan masalah matematis peserta didik. Penelitian ini merupakan penelitian kuantitatif jenis eksperimen semu. Teknik analisis data menggunakan uji normalitas dengan uji Liliefors dan uji homogenitas dengan uji Barlett. Uji hipotesis menggunakan uji ANAVA satu arah dengan sel yang tidak sama. Hasil dari penelitian ini adalah terdapat pengaruh model pembelajaran Auditory, intellectually, Repetition (AIR) dengan pendekatan lesson study terhadap kemampuan pemecahan masalah matematika. Berdasarkan hasil uji lanjut yang menggunakan ujia scheffe' deproleh hasil bahwa model pembelajaran AIR dengan pendekatan lesson study memberikan hasil yang lebih baik dibandingkan model pembelajaran AIR dan konvensional, serta model pembelajaran AIR lebih baik dibandingkan model pembelajaran konvensional.
\end{abstract}

Kata kunci: AIR, Lesson Study, Problem Solving.

\begin{abstract}
The purpose of this study is to determine whether there is a difference in the average implementation of learning model, intellectual, repetition (AIR) with lesson study approach to the problem solving ability of mathematical learners. This research is a quantitative research type of quasi experiment. Data analysis technique using normality test with Liliefors test and homogeneity test with Barlett test. Hypothesis test using one-way ANOVA test with unequal cells. The result of this research is there is influence of learning model of Auditory, intellectually, Repetition (AIR) with lesson study approach to math problem solving ability. Based on the results of further test using scheffe test, the result shows that AIR learning model with lesson study approach gives better result than AIR and conventional learning model, and AIR learning model is better than conventional learning model.
\end{abstract}

Keyword: AIR, Lesson Study, Problem Solving.

\section{PENDAHULUAN}

Pendidikan adalah usaha untuk menyiapkan seorang manusia melalui kegiatan bimbingan, pengajaran, dan latihan yang diharapkan berguna bagi peranannya di masa yang akan datang (Susandi \& Widyawati, 2017). Pendidikan juga merupakan inspirator dalam memperbaiki moral bangsa (Kesuma, 2017). Tanpa melalui proses pendidikan tidak mungkin suatu manusia dapat berkembang sejalan dengan aspirasi (cita-cita) untuk maju, sejahtera dan bahagia. Sejalan dengan hal itu tentunya pendidikan tidak bisa dipisahkan dengan mata pelajaran Matematika, karna pelajaran matematika adalah pelajaran yang kompleks dari semua tingkatan.

Matematika merupakan salah satu pelajaran yang sangat penting, dalam mempelajari matematika diharapkan 
Desimal, 1 (1), 2018 - 2

Elma Agustiana, Fredi Ganda Putra, Farida

peseta didik bukan hanya mengerti, tetapi paham dengan apa yang dia pelajari (Gusnidar, Netriwati, \& Putra, 2017). Di dalam mempelajari ilmu matematika, peserta tidak hanya dituntut untuk menghafal rumus-rumus, akan tetapi lebih pada kebermanfaatan ilmu matematika bagi dirinya sendiri. Kebermanfaatan pada proses pembelajaran matematika dapat dilihat dengan kesadaran apa yang dilakukan, apa yang dipahami dan apa yang tidak dipahami oleh peserta didik (Putra, 2017). Salah satu kemampuan penting dalam pembelajaran matematika adalah pemecahan masalah matematis (Wulandari, Mujib, \& Putra, 2016). Pemecahan masalah merupakan proses dalam menggunakan (yaitu mentransfer) pengetahuan dan keterampilan yang sudah ada untuk menjawab pertanyaan atau permasalahan yang selanjutnya (Ormrod, 2008). Pemecahan masalah dapat terjadi secara nyata pada semua domain konten (content domain). Pemecahan masalah ialah pusat pembelajaran matematika (Widyastuti, 2015). Dengan belajar memecahkan masalah, maka peserta didik diberi banyak kesempatan untuk menghubungkan ide matematika dan untuk mengembangkan pemahaman konseptual. Tetapi pada kenyataannya, lagi-lagi kemampuan pecahan masalah dalam matematika tetap menjadi permasalah yang paling mendasar.

Model pembelajaran Auditory, Intelectually, Reptition (AIR) dapat menjadi solusi untuk diterapkan. Model pembelajaran Auditory, Intelectually, Reptition (AIR) berasal dari kata Auditory yang bermakna bahwa belajar haruslah dengan melalui proses yang dimulai mendengarkan, menyimak, berbicara, persentasi, argumentasi mengemukakan pendapat dan menanggapi. Intelectually bermakna bahwa belajar haruslah menggunakan kemampuan berpikir. Terakhir Repetition, yang bermakna pengulangan dalam konteks pembelajaran. Pemilihan model pembelajaran AIR ini juga karena merupakan salah satu model yang efektif untuk meningkatkan hasil belajar peserta didik (Qurotuh, Nila, \& Mujiyem, 2012; Mawaddah, 2009).

Upaya yang dilakukan penulis untuk membedakan penelitian ini dengan penelitian terdahulu adalah dengan mengkombinasikan antara model pembelajaran AIR dan pendekatan pembelajaran, yang diharapkan dapat lebih membuat peserta didik aktif dalam pembelajaran. Salah satu pendekatan yang dapat diterapkan adalah Lesson study. Semua komponen kegiatan belajar mengajar pada pembelajaran lesson study seperti guru, peserta didik, metode pembelajaran dan lain-lain diperhatikan. Lesson study tidak hanya sekedar kegiatan untuk mengatasi pembelajaran pada suatu kelas, tetapi kegiatan ini lebih kepada membangun suatu jalur atau pola untuk mengatasi kegiatan instruksional yang sedang berjalan. Penerapan pembelajaran lesson study juga sudah pernah dilakukan oleh Riandi, dalam peneliatiannya dia sering menemukan beberapa masalah di sekolah - sekolah dengan tenaga pengajar yang kurang inovatif tentang pola pembelajaran, untuk itulah lesson study hadir dengan membawa tahap - tahap yang dapat meningkatkan keprofesionalan tenaga pendidik, dimulai dari perencanaan, pelaksanaan dan refleksi. Tahapan lesson study tersebut akan membuat tenaga pendidik dan peserta didik akan memberikan hasil belajar yang lebih baik dibandingkan pembelajaran konvensional. Proses penelitian lesson study melibatkan beberapa guru unuk mengamati proses pembelajaran yang dilakukan oleh peneliti. Lesson study dilakukan dalam tiga tahapan, yaitu: (1) Perencanaan (plan), (2) Pelaksanaan (do), (3) Melihat (see). 
Desimal, 1 (1), 2018 - 3

Elma Agustiana, Fredi Ganda Putra, Farida

Tujuan diadakannya penelitian Model pembelajaran Auditory, Intelectually, Reptition (AIR) dengan pendekatan Lesson Study adalah untuk mengetahui Apakah terdapat perbedaan rata-rata penerapan model pembelajaran Auditory, Intelectually, Repetition (AIR) dengan pendekatan lesson study terhadap kemampuan pemecahan masalah matematis pada peserta didik. Manfaat penelitian ini adalah dapat dijadikan alternatif model pembelajaran untuk diterapkan dalam pembelajaran matematika, serta dengan dilakukannya penelitian ini maka akan diketahui ada tidaknya pengaruh pemecahan masalah matematis peserta didik, demi meningkatkan kualitas pembelajaran matematika.

\section{METODE}

Pada penelitian ini yang digunakan adalah penelitian kuantitatif dengan metode Quasi Eksperimental Design. Teknik pengumpulan data yang digunakan dalam penelitian ini adalah tes, dokumentasi, wawancara dan observasi. Instrumen penelitian yang digunakan adalah tes kemampuan pemecahan masalah matematis. Uji hipotesis data dalam penelitian ini menggunakan uji Anava satu arah sel tak sama(Novalia \& Syazali, 2013).

\section{HASIL DAN PEMBAHASAN}

Nilai rata-rata kemampuan pemecahan masalah matematis peserta didik kelas Auditory, Intelectually, Repetition (AIR) dengan pendekatan Lesson Study (eksperimen 1) adalah 81,39, rata-rata kelas Auditory, Intelectually, Repetition (AIR) (eksperimen 2) sebesar 74,16, dan ratarata kelas konvensional (kontrol) sebesar 66,47 .

Sebelum melakukan uji hipotesis, terlebih dahulu dilakukan uji prasyarat hipotesis. Uji prasyarat tersebut meliputi uji normalitas sebaran data dan uji homogenitas varians. Uji normalitas dilakukan pada data kemampuan pemecahan masalah matematis pada pelajaran matematika kelompok eksperimen 1, kelompok eksperimen 2 dan kelompok kontrol dengan menggunakan analisis uji liliefors. hasil perhitungan dengan menggunakan analisis uji liliefors adalah sebagai berikut:

Tabel 1. Tabel Uji Normalitas

\begin{tabular}{clccc}
\hline No & \multicolumn{1}{c}{ Kelas } & $\boldsymbol{L}_{\text {hitung }}$ & $\boldsymbol{L}_{\text {tabel }}$ & Keputusan Uji \\
1 & Eksperimen 1 $\left(\mathrm{A}_{1}\right)$ & 0,120 & 0,148 & Ho diterima \\
2 & Eksperimen 2 $\left(\mathrm{A}_{2}\right)$ & 0,128 & 0,162 & $\mathrm{H}_{0}$ diterima \\
3 & Kontrol $\left(\mathrm{A}_{3}\right)$ & 0,135 & 0,157 & $\mathrm{H}_{0}$ diterima \\
\hline
\end{tabular}

Berdasarkan pada Tabel 1., dapat disimpulkan bahwa ketiga kelompok penelitian berasal dari populasi yang berdistribusi normal, sehingga penggunaan uji Anava satu jalan sel tak sama dapat dilakukan jika ketiga kelompok penelitian tersebut homogen.

Sumber data uji homogenitas varians sama dengan uji liliefors. Uji homogenitas varian untuk ketiga kelompok menggunakan uji Barlett. Dari hasil perhitungan diperoleh bahwa Fhitung $=5,739$ sedangkan $F_{\text {tabel }}$ pada taraf signifikan 5\% sebesar 5,991 yang berarti Fhitung $<$ Ftabel maka Ho diterima. Dapat disimpulkan bahwa ketiga kelompok penelitian memiliki varians yang homogen.

Berdasarkan hasil uji prasyarat yang telah dilakukan, dapat diketahui bahwa data dari kedua kelompok berdistribusi normal dan memiliki varians yang homogen. Dengan demikian uji hipotesis dengan uji Anava dapat dilakukan. Uji hipotesis yang digunakan dalam penelitian ini adalah uji Anava satu 
Desimal, 1 (1), 2018 - 4

Elma Agustiana, Fredi Ganda Putra, Farida

arah sel tak sama, dengan kriteria pengujian adalah $\mathrm{H}_{0}$ ditolak jika $\mathrm{F}_{\text {hitung }}>$ Ftabel.

Selanjutnya, dilakukan uji analisis variansi dua jalan sel tak sama pada data kemampuan pemecahan masalah matematis. Rangkuman uji analisis variansi (ANAVA) dua jalan sel tak sama disajikan pada Tabel 2. berikut:

Tabel 2. Tabel Uji Anava satu jalan sel tak sama

\begin{tabular}{ccccccl}
\hline Kelompok & JKG & KTK & KTG & F-hitung & F-tabel & kesimpulan \\
$\mathrm{A}_{1}, \mathrm{~A}_{2}$ dan $\mathrm{A}_{3}$ & 19564.718 & 1886.095 & 203.799 & 9.255 & 3.091 & $\mathrm{H}_{0}$ ditolak \\
\hline
\end{tabular}

Berdasarkan tabel 2., dapat disimpulkan bahwa terdapat pengaruh penerapan model pembelajaran AIR dengan pendekatan Lesson Study terhadap kemampuan pemecahan masalah matematis peserta didik. Di karenakan $H_{0}$ ditolak, maka perlu dilakukan uji lanjut pasca anava untuk mengetahui secara signifikan tentang perbedaan rerata masing-masing kelompok penelitian. Berikut rangkuman rerata marginal disajikan pada Tabel 3., berikut:

\section{Tabel 3. Rerata Marginal}

\begin{tabular}{cc}
\hline Model Pembelajaran & Rerata Marginal \\
AIR dengan lesson study $\left(\mu_{1}\right)$ & 81,39 \\
AIR $\left(\mu_{2}\right)$ & 74,16 \\
Konvensional $\left(\mu_{3}\right)$ & 66,47 \\
\hline
\end{tabular}

Pada penelitian ini, uji pasca anava menggunakan uji scheffe'. Uji scheffe dilakukan untuk mengetahui pasangan model pembelajaran mana yang memberikan rata-rata hasil kemampuan pemecahan masalah yang berbeda. Berikut ini adalah hasil dari perhitungan uji scheffe':

Tabel 4. Tabel Uji Scheffe'

\begin{tabular}{ccccccc}
\hline Kelas & $\overline{\boldsymbol{x}}$ & $\mathbf{N}$ & $\mathbf{K T G}$ & $\mathbf{F}_{\text {hitung }}$ & $\mathbf{F}_{\text {tabel }}$ & Kesimpulan \\
$\mu_{1}$ vs $\mu_{2}$ & 81,388 & 36 & 203,799 & 4,608 & 3,091 & $\mathrm{H}_{0}$ ditolak \\
$\mu_{1}$ vs $\mu_{3}$ & 74,161 & 31 & 203,799 & 3,534 & 3,091 & $\mathrm{H}_{0}$ ditolak \\
$\mu_{2}$ vs $\mu_{3}$ & 66,468 & 32 & 203,799 & 0,826 & 3,091 & $\mathrm{H}_{0}$ diterima \\
\hline
\end{tabular}

Berdasarkan Tabel 4. pada hipotesis nol yang pertama, diperoleh kesimpulan bahwa terdapat perbedaan kemampuan pemecahan masalah matematis antara peserta didik yang mendapat model pembelajaran AIR dengan pendekatan lesson study dan model pembelajaran AIR. Dari Tabel 3., dapat disimpulkan bahwa kemampuan pemecahan masalah matematis peserta didik yang mendapat model pembelajaran AIR dengan pendekatan lesson study lebih baik dibandingkan kemampuan pemecahan masalah matematis peserta didik yang mendapat model pembelajaran AIR. Hasil ini sekaligus melengkapi penelitian- penelitian sebelumnya terkait penelitian menggunakan pendekatan lesson study (Jalal, 2014) yang menghasilkan bahwa adanya peningkatan dalam kemampuan pemecahan masalah matematik dengan menggunakan pendekatan lesson study.

Selanjutnya pada hipotesis nol yang kedua di tabel 4., diperoleh kesimpulan bahwa kemampuan pemecahan masalah matematis peserta didik yang menggunakan pembelajaran dengan pendekatan lesson study lebih baik dibandingkan kemempuan pemecahan masalah matemamtis peserta didik yang mendapat model pembelajaran konvensional. Hasil ini sesuai dengan 
penelitian (Ayu, Waluyo, \& Suratno, 2014) dengan hasil bahwa adanya pengaruh model pembelajaran Lesson Study terhadap kemampuan pemecahan masalah yang didukung oleh sikap positif siswa belajar dan diskuasi peserta didik dibandingkan dengan pembelajaran menggunakan model konvensional.

Pada hipotesis nol yang ketiga ditabel 4., kemampuan pemecahan masalah matematis peserta didik yang mendapat model pembelajaran AIR sama dengan kemampuan pemecahan masalah matematis peserta didik yang mendapat model pembelajaran Konvensional. Ini dapat disimpulkan bahwa Peserta didik yang mendapatan pembelajaran model AIR dan Konvensional bahwa tingkat kemampuan pemecahan masalahnya sama.

Berdasarkan Tabel3., perhitungan uji Scheffe' diperoleh Fhitung $=4,608$ dan taraf signifikansi $5 \%$ diperoleh $F_{\text {tabel }}=$ 3,091 sehingga $F_{\text {hitung }}>F_{\text {tabel }}$ yang menunjukkan bahwa $\mu_{1}$ vs $\mu_{2}$ ditolak berarti terdapat pengaruh model pembelajaran Auditory, Intellectually, Repetition dengan pendekatan Lesson Study terhadap kemampuan pemecahan masalah matematis, $F_{\text {hitung }}=3,534$ dan taraf signifikansi $5 \%$ diperoleh $F_{\text {tabel }}=$ 3,091 sehingga $F_{\text {hitung }}>F_{\text {tabel }}$ yang menunjukkan bahwa $\mu_{1}$ vs $\mu_{3}$ ditolak berarti terdapat pengaruh model pembelajaran konvensional dengan pendekatan Lesson Study terhadap kemampuan pemecahan masalah matematis, $F_{\text {hitung }}=0,826$ dan taraf signifikansi $5 \%$ diperoleh $F_{\text {tabel }}=$ 3,091 sehingga $F_{\text {hitung }}<F_{\text {tabel }}$ yang menunjukkan bahwa $\mu_{2}$ vs $\mu_{3}$ diterima berarti Tidak terdapat pengaruh antara model pembelajaran Auditory, Intellectually, Repetition dengan pendekatan Lesson Study terhadap penalaran matematis. Berarti dapat disimpulkan bahwa model pembelajaran Auditory, Intellectually, Repetition (AIR) dengan pendekatan lesson study memberikan pengaruh yang signifikan terhadap kemampuan pemecahan masalah matematis peserta didik.

\section{SIMPULAN DAN SARAN}

Hasil penelitian ini adalah terdapat pengaruh model pembelajaran Auditory, Intelectually Repetition (AIR) dengan pendekatan Lesson Study terhadap kemampuan pemecahan masalah matematis peserta didik. Setelah dilakukan uji lanjut terhadap data tersebut, maka dapat disimpulkan bahwa penerapan model pembelajaran Auditory, Intelectually Repetition (AIR) dengan pendekatan Lesson Study menghasilkan kemampuan pemecahan masalah matematis lebih baik dibandingkan model pembelajaran konvensional dengan pendekatan Lesson Study dan model konvensional.

Dari hasil tersebut, saran penulis kepada peneliti yang akan datang bahwa penerapan model AIR ini merupakan salah satu model yang baik untuk diterapkan serta mengkombinasikan model pembelajaran dengan pendekatan pembelajaran merupakan suatu hal yang positif untuk dilakukan.

\section{DAFTAR PUSTAKA}

Ayu, L. T., Waluyo, J., \& Suratno. (2014). Pengaruh Metode Pembelajaran Diskusi Berbasis Lesson Study terhadap Aktivitas dan Hasil Belajar Biologi dengan Menggunakan Assessment Portopolio (Siswa Kelas X Semester Genap SMA Negeri KalisatT Tahun Ajaran 2012/2013). Pancaran, 3, 111120.

Gusnidar, Netriwati, \& Putra, F. G. (2017). Implementasi Strategi Pembelajaran Konflik Kognitif Berbantuan Software. JEMS: Jurnal Edukasi Matematika dan Sains, 6269. 
Desimal, 1 (1), 2018 - 6

Elma Agustiana, Fredi Ganda Putra, Farida

Indiarsih, M. (2016). Pengaruh Model Pembelajaran Model Auditory Intellectually Repetition Terhadap Kemampuan Pemecahan Masalah Matematis Siswa Sekolah Dasar. Serang: Repository Universitas Pendidikan Indonesia.

Jalal, A. (2014). Implementasi Lesson Study Melalui Pembelajaran dengan Pedekatan Pemecahan Masalah Pada Materi Aplikasi Trigonometri. Delta-Pi: Jurnal Matematika dan Pendidikan Matematika, 3, 54-60.

Kesuma, G. C. (2017). Refleksi Model Pendidikan Pesantren dan Tantangannya Masa Kini. Tadris Jurnal Keguruan dan Ilmu Tarbiyah, 2, 63-74.

Mawaddah, M. (2009). Telaah Nilai-nilai Pendidikan Dalam Cerita Karya Pengarang Cilik. Malang: Diss. University of Muhammadiyah Malang.

No, U.-U. (2003). Tahun 2003 tentang SISDIKNAS. Jakarta.

Novalia, \& Syazali, M. (2013). Olah Data Penelitian Pendidikan. Bandar Lampung: AURA.

Ormrod, J. E. (2008). Psikologi Pendidikan (Membantu Siswa Tumbuh dan Berkembang. Jakarta: Erlangga.

Putra, F. G. (2017). Eksperimentasi Pendekatan Kontekstual Berbantuan Hands On Activity (HoA) Terhadap Kemampuan Pemecahan Masalah Matematik. Al-Jabar: Jurnal Pendidikan Matematika, 8(1), 73-80.
Qurotuh, A., Nila, K., \& Mujiyem, S. (2012). Eksperimentasi Model Pembelajaran Auditory Intellectually Repetition (AIR) Terhadap Prestasi Belajar Matematika Ditinjau dari Karakter Belajar Siswa Kelas VII SMP Negeri Se-Kecamatan Kaligesing Tahun 2011/2012. Kontribusi Pendidikan Matematika dan Matematika dalam Membangun Karakter Guru dan Siswa.

Sugiyono. (2013). Metode Penelitian Kuantitatif, Kualitatif, dan $R \& D$. Bandung: Alfabeta.

Susandi, A. D., \& Widyawati, S. (2017). Proses Berpikir dalam Memecahkan Masalah Logika Matematika Ditinjau dari Gaya Kognitif Field Independent dan Field Dependent. 93-112: NUMERICAL: Jurnal Matematika dan Pendidikan Matematika, 1(1).

Widyastuti, R. (2015). Proses Berpikir Siswa dalam Menyelesaikan Masalah Matematika berdasarkan Teori Polya ditinjau dari Adversity Quotient Tipe Climber. Al-Jabar: Jurnal Pendidikan Matematika, 6, 183-193.

Wulandari, P., Mujib, \& Putra, F. G. (2016). Pengaruh Model Pembelajaran Investigasi Kelompok berbantuan Perangkat Lunak Maple terhadap Kemampuan Pemecahan Masalah Matematis. Al-Jabar: Jurnal Pendidikan Matematika, 7(1), 101106. 